УДК 821.163.41.09 Лалић, И. В. https://doi.org/10.18485/msc50.2019.1.ch55

Јован Делић

\title{
ИВАН В. ЛАЛИЋ КАО ПЈЕСНИК КУЛТУРЕ И ДИЈАЛОГА
}

Овај рад је нацрт за једно замишљено и започето истраживање и у њему се Иван В. Лалић представља као пјесник који моделује културу и успоставља вишесмјеран дијалог са националном традицијом и са поезијом свијета.

Рећи за некога пјесника да је пјесник културе не мора обавезно значити комплимент. То може значити да је ријеч о образованом пјеснику, обично полиглоти, изузетно широке личне културе и високог интелекта, чији је однос према свијету доминантно интелектуалан, рационалистички, и чија је поезија лишена ирационалистичких заноса, па и дубине осјећања. Нијесмо сигурни да би неки пјесник био превише срећан када бисмо његовој поезији приписали поменуте особине, односно недостатке.

Пјесник културе може се разумјети и као плеоназам. Ако је поезија, односно умјетност ријечи, другостепени моделативни систем, будући да моделује један првостепени моделативни систем - језик - и ако је култура скуп другостепених моделативних система, онда је поезија дио културе а пјесник по дефиницији пјесник културе. ${ }^{1}$ Онда су, природно, сви пјесници - пјесници културе, па би и поезију ваљало читати и тумачити у ширем, културном контексту.

Термин пјесник културе може имати оперативног смисла ако под њим подразумијевамо пјесника који саму културу моделује; за кога је култура изазов и предмет пјевања. Управо на таквог пјесника мислимо када говоримо о Ивану В. Лалићу као пјеснику културе и дијалога. Дијалог је при таквом моделовању прва кључна ријеч. И тај дијалог није

1 Теорију о првостепеним и другостепеним моделативним системима развили су припадници тартуско-московске школе. О томе је код нас у више наврата писао Новица Петковић примјењујући њихове ставове на сопствена тумачења наших књижевних дјела и наше културе. Видјети Петковићеве радове: Од формализма ка семиотиии, Београд, 1984; Два српска романа, Београд, 1988. и Словенске пчеле у Грачаниии, Београд, 2007. 
једносмјеран, већ вишесмјеран; није усмјерен само на једног пјесника, један језик или једну националну књижевност, већ на цијело пјесничко сазвежђе, на више језика, на оно што зовемо „европска књижевност”, ма колико то нејасно и непрецизно било, од Библије и античке Грчке до наших дана. Ићи трагом тога дијалога значи неминовно се наћи на терену компаративних истраживања, превасходно откривања и успостављања мреже интертекстуалних релација Лалићеве поезије са лириком свијета. Истраживања овога типа одавно су започета, а радови Никше Стипчевића ${ }^{2}$, Александра Јовановића ${ }^{3}$, Милице Николић ${ }^{4}$, Светлане Велмар Јанковић ${ }^{5}$, Светлане Шеатовић Димитријевић ${ }^{6}$, Радивоја Микића ${ }^{7}$, Предрага

2 Н. Стипчевић, Иван В. Лалић (о Четири канона), Годишюак за 1996, САНУ, 1997, стр. 561-569.

3 А. Јовановић, Поезија српског неосимболизма, Београд, 1994.

А. Јовановић, Иван В. Лалић или висока мера песничке уметности, у: Дела Ивана В. Лалића, I, Време, ватре, вртови, Београд, 1997. стр. 9-83.

А. Јовановић, Узнаку Мнемозине. Лалић и Византија, у: Иван В. Лалић, Верни одсутном прволику. Три византијска круга, Београд, 1966.

А. Јовановић, Стих, слика, емоција и култура, предговор у: Иван В. Лалић, Песме, Београд, 2009, стр. 185-220.

А. Јовановић, Песник зрелог лета, у Иван В. Лалић, песник, уредио Драган Хамовић, Краљево, 1996, стр. 97-112.

А. Јовановић, Духовни патриотизам Ивана В. Лалића или о културно-историјским подстииајима Четири канона, у: Постсимболистичка поетика Ивана В. Лалића, Београд, 2007, стр. 383-396.

4 М. Николић, Mare Mediterraneum Ивана В. Лалића, Београд, 1996.

5 С. Велмар-Јанковић, О поезији Ивана В. Лалића, у: Иван В. Лалић, Песме, Београд, 1987.

С. Велмар-Јанковић, „О првој песми Првог канона Ивана В. Лалића”, у: Сnoменииа Ивана В. Лалића, Београд, 71-83.

С. Велмар-Јанковић, Иван на врху, у: Иван В. Лалић, песник, Краљево, 1996, стр. 15-17.

${ }^{6}$ С. Шеатовић-Димитријевић, Традиција и иновација - интертекстуалност у песништву Ивана В. Лалића, Београд, 2004.

7 Р. Микић, Слика, убрзане и огледало, у: Иван В. Лалић, песник, Краљево, 1996, стр. 69-112.

Р. Микић, Песнички поступак Ивана В. Лалића, Песнички поступак, Београд, 2000.

Р. Микић, Лирски свет Ивана В. Лалића, Книжевне новине, 935/936, XLVII, 01.09.1996. и 15.09.1996.

Р. Микић, Силазак низ време, СКГ, март 1996, Трећа серија, 9/II, III/3.

Р. Микић, Мит о поезији, Песма: текст и контекст, Приштина, 1996.

Р. Микић, Јабука и огледало, Повель, Краљево, бр. 3/4, стр. 48-50.

Р. Микић, Шта је јаче: видљиво или невидљиво, Језик поезије, Београд, 1990. 
Палавестре ${ }^{8}$, Јелене Новаковић ${ }^{9}$, Персиде Лазаревић ди Ђакомо ${ }^{10}$, Александра Петрова $^{11}$, Драгана Стојановића ${ }^{12}$, Тихомира Брајовића ${ }^{13}$, Бојане Стојановић Пантовић ${ }^{14}$, Бојана Јовића ${ }^{15}$, Ане Петковић ${ }^{16}$ и других чине данас цијелу малу библиотеку и представљају одличну оријентацију и подстицај за даља истраживања.

Дијалошка природа Лалићеве поезије се не исцрпљује само у истраживању интертекстуалних релација његових пјесама са лириком свијета. Лалићев дијалог прелази и на терен других умјетности и медија, превасходно музике, а онда и сликарства. Лалићеви наслови каткад имају у себи ознаку музичког жанра: „Римски квартет” ${ }^{\prime \prime}$, „Ровињски

8 П. Палавестра, Простор и звук у Римском квартету Ивана В. Лалића, Споменица Ивана В. Лалића, САНУ, Београд, 2003, стр. 129-134.

П. Палавестра, Песничка визија Медитерана, Кюижевност, Београд, год. 51, књ. 53, бр. 11-12, 1996, стр. 1372-1374.

9 Ј. Новаковић, Иван В. Лалић и франиуска поезија, Споменииа Ивана В. Лалића, САНУ, Београд, 2003, стр. 53-66.

Ј. Новаковић, Франиуски аутори у Лалићевим есејима, Постсимболистичка поетика Ивана В. Лалића, Београд, 2007, стр. 319-344.

${ }^{10}$ П. Лазаревић Di Giacomo, Историјско-културни подтекст наративности песме Acqua alta Ивана В. Лалића, Споменииа Ивана В. Лалића, САНУ, Београд, 2003, стр. 111-128.

П. Лазаревић Di Giacomo, Лалићев италијански итинераријум: „У трагағу за прецизном изражајном синтезом", Постсимболистичка поетика Ивана В. Лалића, Београд, 2007, стр. 265-317.

11 А. Петров, Циклуси у поезији Ивана В. Лалића: Мелиса, у: Постсимболистичка поетика Ивана В. Лалића, уредио Александар Јовановић, Институт за књижевност и уметност, Учитељски факултет, Београд, 2007, стр. 59-92.

12 Д. Стојановић, Поверене у Богородииу, Четири канона Ивана В. Лалића, Книжевна историја, бр. 127, 2005, стр. 553-588.

Д. Стојановић, Поверене у Богородииу, Досије, Београд, 2007.

13 Т. Брајовић, О светлости љубави и юеном одсјају међу мртвима и међу живима, у: Споменица Ивана В. Лалића, САНУ, Београд, 2003, стр. 103-109.

14 Б. Стојановић-Пантовић, Наративност поезије Ивана В. Лалића, у: Постсимболистичка поетика Ивана В. Лалића, Београд, 2007, стр. 93-108.

15 Б. Јовић, Византија и византинизам код К. Кавафија, В. Б. Јејтса, И. В. Лалића и Р. Силверберга, у: Постсимболистичка поетика Ивана В. Лалића, уредник Александар Јовановић, Београд, 2007, стр. 231-263.

16 А. Петковић, Античко наслеђе у поезији Ивана В. Лалића, у: Постсимболистичка поетика Ивана В. Лалића, стр. 215-230.

17 Дела Ивана В. Лалића, I, Време, ватре, вртови, редакција и приређивање Александар Јовановић, Завод за уџбенике и наставна средства, Београд, 1997, стр. 226. 
квартет” ${ }^{18}$, Четири канона ${ }^{19}$, или пак упућују на ликовну умјетност: „Фра Анђелико слика Благовести”20, „Бакропис”21. Не ријетко нас стихови неке пјесме упућују на знамените сликаре, гравере или архитекте (Пиранези, Лонгена, Боромини, Дирер). Тако се интертекстуалне релације проширују на интермедијалне, естетске и културно-историјске. У сваком случају, присуство „гласова мртвих” који „нису мртви гласови” и дијалог са њима једно је од битних обиљежја поезије Ивана В. Лалића.

Дијалог се води са својим духовним прецима и савременицима, а један вид тога дијалога су и Лалићеви есеји о другим пјесницима, утолико значајнији што нас сам Лалић упозорава да такве есеје пише о пјесницима које је бирао у своје духовно сродство, или с намјером да артикулише неке поетичке ставове важне за њега самога и за разумијевање његове поезије. Онај ко испитује природу Лалићевог дијалога у и о поезији и поетици мора као дио тога дијалога читати и Лалићеве есеје. То смо у својим истраживањима чинили и када је ријеч о домаћим као и о страним пјесницима.

У сваком случају Лалићева поезија је изузетно захтјевна за читаоца. Она као да не рачуна на велики круг читалаца. Рекло би се да је више камерна и писана за читаоце пјеснику сличне; читаоце широке личне, не само књижевне културе. За разумијевање те поезије неопходна су озбиљна знања, прије свега књижевна, али и историјска и културноисторијска, богословска, па знања из митологије и познавања страних језика.

Оволика захтјевност знања од читалаца сигурно представља велику „сметњу на везама”. Некада су наслови озбиљна, за многе непремостива препрека у комуникацији. Иако је био велики поштовалац свога језика и националне пјесничке традиције, Лалић је бројне своје пјесме насловљавао на страним језицима или је у наслову користио мало познате стране ријечи: „Алгол”22, „Гласови: Finis Republicae”23, „De administrando

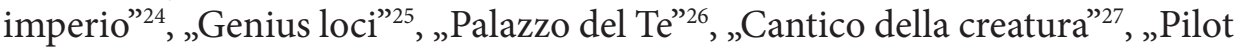

\footnotetext{
18 Дела Ивана В. Лалића, III, Страсна мера, стр. 27-34.

19 Исто, стр. 177-255.

20 Дела Ивана В. Лалића, I, Време, ватре, вртови, стр. 280.

${ }_{21}$ Дела Ивана В. Лалића, III, Страсна мера, стр. 17.

22 Дела Ивана В. Лалића, II, О делима лубави или Византија, стр. 9-16.

23 Исто, стр. 139.

24 Исто, стр. 156.

25 Исто, стр. 198.

26 Исто, стр. 213.

27 Исто, стр. 216.
} 
Point”28, „Looking Glas”29, „Imago ignota”,30, „Kunsthistorisches Museum”31, "Acqua alta”, ",Voyage philosophique”33, „Amor fati” ${ }^{34}$, „Ave Maris Stella”, да наведемо само неке наслове које недовољно образован љубитељ поезије не може ни прочитати, а камоли разумјети. Не споримо оправданост ни функционалност оваквих наслова, али је тешко замисливо масовно читање поезије уз помоћ речника, енциклопедија и других приручника за одгонетање значења ријечи и појмова из митологије, религије, архитектуре и сликарства. Нијесмо сигурни да поезија тиме увијек добија; сигурни смо да један број читалаца одбија.

Лалићева поезија несумњиво јесте дубоко рефлексивна и високо церебрална, али то не значи да је суво рационалистичка и да је лишена заноса и осјећајности. Као пјесник рафиниране религијске осјећајности и тематике, он није могао гајити велико повјерење у ratio, већ у чудо, а нарочито у чудо љубави. Лалић је програмски пјесник љубави, са једном руковети изванредних љубавних пјесама. Пјевати о Богу, а прије и више од свега - о Богородици и Благовестима, значи програмски пјевати о љубави. Али његов најкраћи програм садржан је у оксиморонском наслову Страсна мера ${ }^{36}$, из кога се слути јединство класицистичког и неосимболистичког насљеђа. Страсна мера је истовремено тежња за унутрашњим складом, измирење страсти и мере, али и тежња за складом са Богом и са свијетом; јединство „форме” и најдубљег смисла пјевања. „Изрицати опасност, а бити / Видљивоме веран: ето правога задатка", ${ }^{37}$ одговор је на Хелдерлиново питање: „И чему песници у оскудно време?”38; на ситуацију у којој се пјесник нашао, како ју је описао Зоран Мишић, „на местима врлетним и неприступачним”. „Острастити меру, а елементе мере препознати у страсти", поручује Лалић подсјећајући на Хелдерлинове ријечи према којима „оно што траје заснивају песници”..9

${ }_{28}$ Дела Ивана В. Лалића, III, Страсна мера, стр. 64.

${ }_{29}$ Исто, стр. 69.

30 Исто, стр. 70.

31 Исто, стр. 77.

32 Исто, стр. 83.

33 Исто, стр. 131.

34 Исто, стр. 147.

35 Исто, стр. 163.

36 Тако је насловљена збирка пјесама из 1984. и трећа књига Дела Ивана В. Лалића.

37 Дела Ивана В. Лалића, II, О делима тубави или Византија, стр. 265-266.

38 Дела Ивана В. Лалића, IV, О поезији, стр. 271.

39 Исто, стр. 271. 
Зато није чудо што исти историчар и тумач књижевности, Александар Јовановић, види Ивана В. Лалића као неосимболисту и посткласицисту. ${ }^{40}$ То не мора бити, и по нашем мишљењу није, контрадикторно. Штавише, то је у српској националној традицији: није ли Војислав Илић био не само претеча већ и први пјесник српског симболизма, а био је сљедбеник класицизма и творац најљепшег, најприроднијег и најеластичнијег српског (псеудо)хексаметра. Војислав Илић је један од првих националних пјесника према коме се одређује Иван В. Лалић; то је пјесник који је усмјерио главни ток српске поезије којим ће она кренути на почетку XX вијека. Лалић је у много чему Илићев сљедбеник, а посебно у односу према класицизму и симболизму.

Лалић је, наиме, несумњиво сљедбеник класицистичке традиције по својој учености, по оријентацији на класичне вриједности, по знању свјетских језика, по упућености на форму и по његовању у обнављању и иновирању класичних и других старих облика, по усмјерености на традицију, по дистанци од радикалних авангардних, превасходно дадаистичких и надреалистичких експеримената, по рефлексивности, по склоности ка цитатима, по високој пјесничкој самосвијести и по потреби да своју поезију артикулише било у есејима о књижевности, у које убрајамо и интервјуе, било у својим пјесмама, по везивању за традицију класицистичке поезије у националној (Стерија, Војислав Илић) и свјетској књижевности (Хомер, Вергилије, Хелдерлин, Гете, Рилке, Т. С. Елиот).

Али Иван В. Лаић је, несумњиво, и баштиник симболистичког насљеђа. За њега симболизам није ни правац, ни школа, ни стилска формација, већ дио пјесничке стратегије, нешто готово иманентно поезији. Зато он држи до сугестивности, опјева и тематизује однос видљиво-невидљиво ослањајући се превасходно на звучне и визуелнне пјесничке слике. Није случајно што су Лалићеве антологије француске ${ }^{41}$, америчке ${ }^{42}$ и њемачке ${ }^{43}$ поезије усмјерене на модерну, постромантичарску поезију,

40 А. Јовановић, Поезија српског неосимболизма, Београд, 1994.

Постсимболистичка поетика Ивана В. Лалића, уредник Александар Јовановић, Београд, 2007.

Модерни класициста Јован Христић, уредник Александар Јовановић, Београд, 2009.

${ }^{41}$ Антологија новије франиуске тирике од Бодлера до наших дана, приредио и превео Иван В. Лалић, Просвета, Београд, 1966.

42 Антологија модерне америчке поезије, изабрао и приредио Иван В. Лалић, превод: Бранка Лалић и Иван В. Лалић, Просвета, Београд, 1972.

43 Антологија немачке лирике XX века, приредили Иван В. Лалић и Бранимир Живојиновић, Нолит, Београд, 1976. 
од симболизма па до средине XX вијека. Спиритуалност Лалићеве поезије и усмјереност на дијалог с Богом такође говоре у прилог присуству симболистичког насљеђа.

Иван В. Лалић води интензиван дијалог с националном књижевном и културном традицијом, одређујући се врло прецизно према њеним вриједностима. Пјеснику је унапријед задато вријеме у којем живи са свим историјским збивањима које оно собом носи и задат му је језик на којем ће проговорити и пропјевати. Самим тим задата му је и традиција националне књижевности којој припада као духовно насљеђе које му ваља освојити и усвојити, али изван којега и без којега тешко да нешто може значити. Настојање појединих пјесника да се омаловажи национална традиција зарад неког мутног космополитизма Иван В. Лалић назива провинцијалним. Пјеснику ваља да успостави сопствени избор из традиције и „стуб сећања”, како би рекао Миодраг Павловић. Лалић у интервјуу из 1970. дословно каже:

„Споменули сте духовни провинцијализам у склопу са појмовима 'усконационалног' и 'локално егзотичног'. Чини ми се да се такав провинцијализам може да изражава - и да се изражава - једнако кроз својеврсне космополитске аспирације. Провинцијалан је дух који одбија да се сећа, који се одриче својих координата заданих у језику - у традицији, историји, судбини, духовном простору тог језика. (Ко не повуче поуке из Лазе Костића или Војислава Илића узалуд ће их тражити код Малармеа или Рилкеа.)"44

Због тога нам се као први круг било наметнуло испитивање Лалићевог односа према националној традицији и реконструисање дијалога с пјесницима новије српске књижевности, од Стерије на овамо. Ваљало је испитати - и ваљало би истраживање допунити - Лалићев однос према Стерији, Војиславу Илићу, Лази Костићу, пјесницима српског симболизма, прије свих према Милану Ракићу, Јовану Дучићу и Милутину Бојићу, па према њиховом теоретичару, критичару и антологичару Богдану Поповићу, „пантологичару” и пародичару Станиславу Винаверу, а онда према Растку Петровићу, Васку Попи, Миодрагу Павловићу и Бранку Миљковићу, а нарочито према критичару српских послератних модер-

Све три Лалићеве антологије су поново објављене у Заводу за уџбенике и наставна средства у Источном Сарајеву, под уредништвом и са предговорима Јована Делића, 2005, године.

${ }_{44}$ Дела Ивана В. Лалића, IV, О поезији, стр. 268. 
ниста Зорану Мишићу. Показало се да је тиме обављен мањи дио посла у проучавању дијалогичности Лалићеве поезије.

Ваљало би поћи трагом истраживања Злате Бојовић која је освијетлила Лалићев однос према Дубровнику, ${ }^{45}$ његовој култури и књижевности. Наш пјесник је, несумњиво, ту књижевност и културу сматрао својим духовним завичајем. Цио пети циклус у Збирци Круг носи наслов Дубровник, зимска прича ${ }^{46}$ и састављен је од дванаест пјесама. Овај градрепублика са својом књижевношћу био је за Лалића једна од најсвјетлијих тачака Медитерана.

Духовни завичај за Ивана В. Лалића није нешто једнострано и дводимензионално, нити нешто наслијеђено као имање, већ би се могао представити као „систем концентричних сфера” у којем своје мјесто имају Византија, Медитеран и Грчка. Византији би припадало средишње мјесто у том „систему сфера”.

Византија никада за Лалића није страна цивилизација и култура, већ извориште сопствене културе. Преко ње се успоставља поријекло, континуитет и цјелина националне књижевности и културе, али будући да је Византија и велика културна синтеза, насљедница античке Грчке и античког Рима, преко ње се успоставља и дијалог са традицијом свих традиција, са античком Грчком, односно са римском књижевношћу и културом. Она је у своје темеље уградила Стари и Нови завјет и уздигла јудеохришћанску цивилизацију до неслућених висина. Дијалог са Византијом значи и успостављање дијалога с Библијом, односно с Богом, толико карактеристичног за ово пјесништво; отуда и жанр молитве и обнова канона. Отуда у Лалићевом пјесништву толико присуство библијских цитата и мотива. Библија је несумњиво најцитиранија књига у Лалићевом пјесништву. Уосталом, то и није књига, већ библиотека. Дијалог с Византијом Лалић је започео првом својом књигом Бивщи дечак ${ }^{47}$, а окончао га је својим ремекдјелом и завршеном књигом у свом опусу - Четири канона ${ }^{48}$, књигом која је сва у знаку обнове једног византијског жанра.

Византија никада није за Лалића страна цивилизација и култура, већ извориште сопствене културе. Византија је наставила да траје у народима који су се у њој и уз њу духовно и културно обликовали, који су

45 3. Бојовић, Дубровник - Зимска прича Ивана В. Лалића $и$ Кључеви светог Влаха Љубомира Симовића, МСЦ, 34/2, 2005, стр. 367-374.

Прештампано у: Стари Дубровник у српској къижевности, Службени гласник, Београд, 2010, стр. 153-161.

${ }_{46}$ Дела Ивана В. Лалића, II, О делима льубави или Византија, стр. 129-141.

${ }^{47}$ I. V. Lalić, Bivši dečak, Lykos, Zagreb, 1955.

${ }^{48}$ И. В. Лалић, Четири канона, Српска књижевна задруга, Београд, 1996. 
њеним посредством примили хришћанство, писмо и културу, наслиједили цијелу једну богату књижевност, обукли се у историју изашавши из варварства. То су они народи „од глине” који су се тек културноисторијски обликовали у контакту са Византијом, а међу њима су и Срби. Зато је Лалићев дијалог са Византијом истовремено и дијалог са српском средњовјековном књижевношћу и историјом, са Светим Савом и Стефаном Првовенчаним, са Теодосијем и Доментијаном, са деспотом Стефаном Лазаревићем и његовим „Словом љубве” које се цитира у пјесми „Рашка"49. Захваљујући укоријењености у Византији, Јован Дамаскин постаје дио и српске културе и традиције као иконописац, пјесник и реформатор канона, као музичар, дародавац треће руке Богородици Тројеручици, култној хиландарској икони, заштитници српског народа и игуманији српскога гнијезда у Богородичином храму - манастира Хиландара. Преко Јована Дамаскина успостављена је присна веза по временској вертикали са Лазом Костићем и са пјесничко-музичким жанром канона, који ће Иван В. Лалић обновити, иновирати и модернизовати у својој посљедњој збирци Четири канона. Та збирка је најочевиднији израз византијског насљеђа у Лалићевом пјесништву, више него ли циклус пјесама с насловом „Византија” (I-X). Најзад, жанр молитве долази из исте традиције, а Лалићева пјесма „Шапат Јована Дамаскина” 50 једна је од најљепших модерних молитава. Историја и агонија Византије продужава се, за Лалића, у српској историји, па пад Византије није се збио падом Константинопоља, већ падом Смедерева. Зато је Византија духовни завичај, сурова учитељица, сан о успостављању духовних и историјских вертикала, континуитета и цјелине; сан о цјелини и дубини памћења. Она је „остарело сунце”, „мртва светлост”, „дивно мртво чудо у зеницама времена”, „усамљена мудрост”, „лепота која се не опрашта”, а пјесник је „скутоноша њене попљуване сенке”; њен заступник у дијалогу с Венецијом чија је историјска кривица за пропаст Византије пресудна.

Александар Јовановић је убједљив када показује да се унутар Лалићевог циклуса о Византији може формирати асоцијативни циклус Српска Византија чијим се пјесмама тематизује новија, па и најновија српска историја („Смедерево”, „Фреска”, „Писмо господина Синадина”, „Смрт са соколом”, „1804”, „Ресава”, „Принцип на бојишту”, а њима бисмо могли додати и Четири канона). ${ }^{51}$

49 Дела Ивана В. Лалића, II, О делима љубави или Византија, стр. 177.

50 Дела Ивана В. Лалића, III, Страсна мера, стр. 161.

51 Иван В. Лалић, Верни одсутном прволику / Три византијска круга, избор, приређивање и поговор Александар Јовановић, Народна књига, Алфа, Београд, 1996. 
Лалићево пјесништво није само дијалог са Византијом, већ је и одбрана Византије и византијског духовног насљеђа. Наш пјесник успоставља каткад источно-западни диван између хришћанског Истока и хришћанског Запада, као у првој пјесми с насловом „Византија”52, а нарочито у пјесми „Aсqua alta” ${ }^{3}$, гдје се води дијалог између Византије и Венеције.

О Лалићевом дијалогу с антиком већ су писале Светлана Шеатовић Димитријевић и Ана Петковић. Грчки митови и митски јунаци моделовани су лирски у Лалићевом пјесништву (Орфеј, Еуридика, Аргонаути, Икар, Атлантида), али и вјечни Одисеј, јунак свјетске књижевности XX стољећа, и несрећни непослушни младић Елпенор из његове дружине. Ана Петковић показује интертекстуалне везе Лалићевих стихова са Хераклитом из Ефеса („Хераклит Мрачни”) ${ }^{54}$, Пиндаром („Фрагмент”) Вергилијем и Тацитом („Над Тацитом”) ${ }^{56}$. Лалићев дијалог с антиком и Византијом доводи нашега пјесника у духовну близину Кавафија, Елиота и Јејтса.

Медитеран као културни круг, као колијевка европске културе, са свим својим културним слојевима и језицима, дио је Лалићевог духовног завичаја. За тај простор био је готово судбински везан и Лалићев пријатељ, пјесник Јован Христић.

Ништа лакше и ништа погрешније него помислити како је Иван В. Лалић - заступник Византије у спору са Венецијом и скутоноша њене попљуване сјенке - противник и негатор западно-хришћанске културе. Он не само да то није, већ управо као пјесник љубави и скутоноша попљуване сјенке Византије то не може бити. Мало је српских пјесника који су у тако дубоком и интензивном дијалогу са западном културом као што је то био Иван В. Лалић: као читалац, као пјесник, као преводилац, као антологичар, као приређивач појединих дјела и избора, као есејиста и писац предговора. Зато ми мислимо да се Лалићев преводилачки и антологичарски рад може разумјети као својеврстан интеркултурални дијалог. Подсјетимо се: Иван В. Лалић је преводио Петрарку, ${ }^{57}$ заносио се идејом да преведе Дантеову Комедију, сачинио је и превео на српски Антологију новије франиуске тирике од Бодлера до наших дана, Антологију модерне

52 Дела Ивана В. Лалића, I, Време, ватре, вртови, стр. 139.

53 Дела Ивана В. Лалића, III, Страсна мера, стр. 83.

54 Дела Ивана В. Лалића, II, О делима љубави или Византија, стр. 172.

55 Дела Ивана В. Лалића, III, Страсна мера, стр. 146.

56 Дела Ивана В. Лалића, II, О делима лубави или Византија, стр. 224.

57 Ф. Петрарка, Канияониер, превели: О. Делорко, С. Раичковић, Љ. Симовић и Иван В. Лалић, Гутенбергова галаксија, Београд, 1996. 
америчке поезије за коју је пјесме превео заједно са супругом Бранком и, заједно са Бранимиром Живојиновићем, Антологију немачке лирике XX века ${ }^{58}$, за коју су коришћене услуге више преводилаца.

Лалићев доживљај Италије је снажан, дубок и амбивалентан. Многа мјеста која је волио налазе се у Италији; мјеста интимне љубави, спојена са љепотом града, вртова, тргова. Рим је, несумњиво, такво мјесто.

Лалић је преводио Петрарку и смјерао је да преведе Дантеову Комедиjy. Петраркин сонет му је остао образац идеално уређеног односа међу катренима и терцетима. Зато, кад год говори о „сонетном зглобу”, по правилу призива Петрарку. То никако не значи да је Лалић био конзервативан сонетиста. Напротив, уводио је иновације са пуном свијешћу о традицији. Дантеа је често призивао, или на њега алудирао, кад је био усмјерен на Божанско, на Бога и Богородицу. Отуда Данте често у Канонима, али и тамо гдје га је теже препознати, гдје Лалић у први план истура Монталеа.

Без обзира што је италијански културноисторијски подтекст Лалићеве поезије вјероватно најбоље истражен - урадили су то Никша Стипчевић ${ }^{59}$ и Персида Лазаревић ди Ђакомо ${ }^{60}$ - вјероватно би се тек само понешто у инетрпретацијама могло додати.

Персида Лазаревић ди Ђакомо, подстакнута радовима Предрага Палавестре ${ }^{61}$, уочава двије битне цјелине у поезији Ивана В. Лалића о Италији - Медитеран и Византију. Пјесме које тематизују Рим и околи-

58 Видјети напомене 41, 42, 43.

59 Н. Стипчевић, Учитаваға, Завод за уџбенике и наставна средства, Београд, 1999, стр. 35-53.

${ }^{60}$ П. Лазаревић Di Giacomo, Одраз италијанске стварности у поезији Ивана В. Лалића, у: Научни састанак слависта у Вукове дане, бр. 37, 2008, стр. 463474.

П. Лазаревић Di Giacomo, Историјско-културни подтекст наративности песме Acqua alta Ивана В. Лалића, у: Споменица Ивана В. Лалића, САНУ, 2004, стр. 111-127.

П. Лазаревић Di Giacomo, Лалићев италијански итинераријум, у: Постсимболистичка поетика Ивана В. Лалића, Институт за књижевност и уметност, Учитељски факултет, Београд, 2007, стр. 265-318.

${ }^{61}$ П. Палавестра, Драж и искушене пустоловине, Книжевне новине, 12/147, 13.9.1961.

П. Палавестра, Песничка визија Медитерана, Политика, 16.11.1969. Под истим насловом штампан је рад у часопису Книжевност, г. 51, књ. 53, бр. 11-12, 1996.

П. Палавестра, Простор и звук у Римском квартету Ивана В. Лалића, у: Сnoменииа Ивана В. Лалића, САНУ, Београд, 2003, стр. 139. 
ну („Тиренско море”62, „Римски квартет”63, „Римска елегија”64) припадале би медитеранском тематском кругу, док пјесме усмјерене на Венецију и Лагуну, а нарочито „Aсqua alta”65, успостављају лирско-историјски спор између Венеције и пјесничког субјекта око историјске кривице Млетачке републике за пропаст и пљачку Византије у крсташким ратовима. Том кругу припадају и пјесме „Излет у Торчело”66, „Мнемозина”67, „Јоана из Равене”68. Отуда у пјесмама из „Млетачке Византије” присуство теме смрти и дубоке меланхолије над историјом. Вјероватно ни један српски пјесник није са тим интензитетом доживљавао Италију и њене различите културне слојеве и значења као што ју је доживљавао Иван В. Лалић.

Вјероватно је најмање испитан Лалићев однос према енглеској традицији. Наравно да је одмах уочен однос према Шекспиру: Шекспирови јунаци, Хамлет и Офелија, нашли су свој одјек у Лалићевом пјесништву, али са самосвијешћу да су их већ премоделовали Рембо и Георг Хајм.

Француска поезија је са Бодлером и послије Бодлера избила у врх свјетског пјесништва и скоро стотинак година снажно, готово пресудно дјеловала на лирику свијета. О Лалићевом односу према француској поезији и критици написала је два врло информативна рада Јелена Новаковић, ${ }^{69}$ потврђујући жив и интензиван интертекстуални дијалог нашега пјесника са француским пјесништвом, посебно са Бодлером, Рембоом, Клоделом, Ревердијем и Боскеом. О поезији Алена Боскеа ${ }^{70}$ и Пјера Жана Жува ${ }^{71}$ написао је посебне огледе. За своје симболистичко насљеђе Иван В. Лалић највећма треба да захвали Французима: Бодлеру, Рембоу и Валерију прије свих. Бодлера је сматрао најзначајнијим и најутицајнијим пјесником друге половине 19. вијека и цитира га у пјесми „Три снимка клипера Cutty Sark"72. Са Рембоом га везује и тема Офелије, иако ће Лалићева лирска слика Офелије бити ближа њемачком пјеснику Георгу Хај-

62 Дела Ивана В. Лалића, I, Време, ватре, вртови, стр. 219.

63 Исто, стр. 226.

64 Дела Ивана В. Лалића, III, Страсна мера, стр. 148.

${ }^{65}$ Исто, стр. 83.

66 Дела Ивана В. Лалића, II, О делима лубави или Византија, стр. 214.

${ }_{67}$ Исто, стр. 255-258.

68 Исто, стр. 117.

69 Видјети напомену бр. 9.

${ }^{70}$ И. В. Лалић, „О поезији Алена Боскеа“, у: Ален Боске, Белешке за једну самоћy, Крушевац, Багдала, 1972.

71 Дела Ивана В. Лалића, IV, О поезији, стр. 178-172.

72 Дела Ивана В. Лалића, III, Страсна мера, стр. 135. 
му. Са Клоделом и Жаном Жувом спаја га хришћанска тематика. Клоделове стихове је исписивао припремајући се за своје пјесничке пројекте.

Оно што је Бодлер био за другу половину XIX, то је Елиот за XX стољеће: најутицајнији пјесник, али и мислилац о књижевности. Елиот је веома значајан и за Лалићеву поезију и поетику, и за Лалићеву мисао о књижевности, било да је ријеч о односу поезија-музика, односу према Дантеу или класицизму, или пак о цитатности, о односу према Богу и свијету, о језичкој прецизности и економичности, о цјелини и цјеловитости пјесничког дјела, о пјесничкој слици као јединству чулног и мисаоног, о објективном корелативу, о историјском осјећању и односу према традицији, о аудитивној имагинацији.

Лалићева антологија америчке поезије јесте откриће цијелог једног пјесничког континента и одавање посебног признања Волту Витмену за велики преокрет у концепцији стиха и ритма. То је поезија која је битно одређивала токове свјетске лирике у XX стољећу, а иновације у свјетску лирику су уносили Емили Дикинсон, Езра Паунд, Т. С. Елиот, Силвија Плат и многи други велики амерички пјесници.

Иван В. Лалић изузетно пуно дугује Њемцима. Тешко да му је неко ближи од Ф. Хелдерлина и Р. М. Рилкеа када говори о природи пјесништва и „чему пјесници у оскудно вријеме”. У подтексту Лалићеве „Римске елегије” налазе се Гетеове „Римске елегије”7з. „Офелија” Георга Хајма ближа му је од Шекспирове и Рембоове. С Рилкеом га повезују идеје о односу лијепог и страшног и бројне фине интертекстуалне релације. Осјећање самоће у љету и љубав према Средоземљу зближавају га са Готфридом Беном, а Целанов оксиморон „црно млеко” и плави мајстор смрти из Немачке јављају се у Лалићевим Канонима.

Као својеврстан интеркултурни дијалог може се разумјети и Лалићев однос према пјесничким облицима, односно према облицима стиха и строфе: с једне стране отвореност према хексаметру, пентаметру и елегијском дистиху показује живу везу с антиком и класицистичком традицијом; с друге, канон као пјесничко-музички облик и молитва као пјеснички жанр потврђују присан однос према српсковизантијској традицији; с треће, станца, страмбото, терцет, катрен, сонет, јампски једанаестерац потврђују присуство романских облика и повезују Лалићево пјесништво с италијанском и француском традицијом. Лалићев слободни, а он би радије рекао невезани стих, свједочи о специфичном грађењу модерних ритмова: један тип овога стиха настао је декомпоновањем

${ }^{73}$ Упоредити: J. Volfgang Gete, Pesme, BIGZ, Beograd, 1977, стр. 47-63. 
(псеудо)хексаметра. Све ово показује изузетну пјесникову ширину и отвореност.

Озбиљно читање поезије каква је поезија Ивана В. Лалића немогућно је изван интеркултурнога дијалога са различитим националним књижевностима и културама, па и са цијелим културним круговима (Византија, Медитеран). Чак и када се расплету све сложене дијалошке релације остаје велико питање колико смо ваљано прочитали саму поезију. А Иван В. Лалић јесте био велики пјесник, барем колико и велики посредник међу културама. Свим сметњама на везама упркос, Лалићева поезија ће имати одабране и посвећене читаоце, а ти читаоци ће још дуго имати посла с Лалићевим пјесмама.

\section{Jovan Delić}

IVAN V. LALIĆ, A POET IN DIALOGUE WITH CULTURE

\section{Summary}

This paper problematizes the phrase a poet in dialogue with culture and interprets it as a phrase that denotes a poet who shapes culture and enters into $a$ dialogue with national tradition and world poetry. This paper is a draft of the research, already done in part and in part yet to be done, on the attitude of Ivan V. Lalić towards the culture of ancient Greece, Byzantium, the Mediterranean, Bible and Judeo-Christian tradition, and particularly towards Italian, French, English, American, and German poetry. 